\title{
SIGNIFICANT DIFFICULTIES IN LEARNING TO READ AND WRITE IN PRIMARY EDUCATION: A SET OF TASKS TO DEAL WITH THESE DIFFICULTIES BY MEANS OF A DIDACTIC APPROACH
}

\author{
M. Ester Romero Mariscal \\ Dr. Juan Antonio Lopez Núñez \\ University of Granada, Spain
}

\begin{abstract}
This article focuses on two main issues. On the one hand, it deals with early prevention of literacy difficulties. On the other hand, it deals with the same issue once pupils already present serious difficulties in reading and writing. Consequently, this paper has two main aims. Firstly, it aims to show teachers that, in order to carry out appropriate pedagogical intervention, it is essential to design educational intervention programmes based on thorough theoretical bases. These will aid the teaching of literacy skills while improving the learning process of pupils who require special treatment. Secondly, it intends to provide teachers with a series of activities that can be used with pupils who already present significant difficulties in this particular area of primary learning, i.e. reading and writing, and whose assessment reports already reflect these difficulties. The educational intervention presented in this paper focuses on a particular child whose mother tongue is Spanish. Thus, all the activities proposed as well as the texts they are based upon are in Spanish.
\end{abstract}

Keywords: Teaching of reading and writing, literacy skills, learning difficulties, difficulties in learning to read and write, prevention and intervention against difficulties in learning to read and write in primary education

\section{Introduction}

In my professional experience as a primary teacher, I have confirmed that teachers often encounter some children who present serious literacy difficulties. In general, although we are aware that identifying a possible dyslexia is a complex process, we should not delay taking action during the 
first stages of these complications, which involve obvious reading and writing underachievement in relation to the child's peers.

This situation becomes even worse, and so does the need to take care of it, during the last years of primary education. Therefore, it is important to establish a set of measures which will include daily work with these pupils, careful observation of their literacy development, and identification of risk factors, among others. Besides, it is essential to involve both the school's Educational Psychologist Team, and the pupils' families, as they are the ones who know them best.

The experience shared in this paper presents an educational intervention carried out with a nine-year-old learner, who is in his fourth year of primary education and whose mother tongue is Spanish. A detailed report has been issued as regards the different literacy difficulties he presents. This provides us with interesting data that should work as the bases of any appropriate and thorough proposal of intervention with this child. What follows is the information gathered in the report:

1. The boy presents a regular intelligence levels, an IQ score of 101, and he does not struggle with the mastery of basic concepts.

2. His problems regarding educational development all revolve around his literacy difficulties.

3. He is lagging behind as regards curricular progress. His level of curricular competence corresponds to that of second year of primary education.

4. He shows good behaviour at school, good relationships with his peers and the tutor, and he does not cause any problems at home, save for the concern of his parents regarding his underachievement.

5. As regards his learning style, one could say that he lacks independence, needing always to be pointed in the right direction. He usually benefits further from short and segmented tasks.

\section{Literacy acquisition processes, metacognition and metalinguistic awareness}

In order to overcome literacy difficulties, one must pay close attention to the processes involved in literacy acquisition, as well as the cognitive abilities and metalinguistic awareness of the pupil at hand.

The processes involved in literacy acquisition are very complex in themselves. From the moment we look at a text and perceive a series of graphical symbols to the moment we decipher and understand what is written, we go through four reading stages, according to Cueto (1990). These processes, related to learners' linguistic and metalinguistic abilities, are the following:

1) Perceptive processes, or acquisition of information from letters and 
perception of words, which span from the perception of symbols to giving meaning to the graphemes. In this sense, the visual input is transformed into linguistic material. Therefore, we establish a grapheme-phoneme association, and we become aware of the phonetic sequence of the sounds that comprise the syllables and the words.

2) Lexical processes, through which we understand the meaning of the words we have already deciphered during the previous process.

3) Syntactic processes, which enables us to determine the relation between the words in a given sentence. By understanding the value of the words and the relations between them, we can access the meaning of a particular sentence.

4) Semantic processes, or text comprehension processes, which distinguish the relation between sentences and their value so as to achieve global understanding. Also, it influences the ability to infer meaning and make judgements about the formal aspects of the text and its content.

In the same way, Flower and Hayes (1981) meticulously describe the subprocesses that comprise the composition of written texts. They distinguish the following ones:

1) Planification, which implies searching for ideas and carrying out a writing plan that considers the purpose of writing, the recipient, the information research or the information layout. In this way, one can turn a pre-text into a text.

2) Textualisation, which means producing a written text with coherence, correction (semantic, syntactic and spelling), and appropriateness (recipient, object described and context).

3) Revision, which involves rereading the text and evaluating the result, which will lead to some corrections or modifications so as to achieve the final result.

Such processes are closely related to the development of metacognition, which can be defined as the knowledge pupils have of the essential mental operations that take place during learning processes (perception, cognition, memory, attention), and the control they have over those operations. It is therefore a human ability which enables us to know our way of learning, to plan activities to access and process information, to know particular ways of solving problems, and to control and value our procedural effectiveness (Antonijevick and Chadwick, 1982). This ability, which appears at an early age and develops fully at adolescence, deserves special attention on the part of teachers, owing to the fact that literacy performance depends on it to a large extent.

As regards metalinguistic awareness and literacy acquisition, Tunmer, Pratt and Herriman (1989) claim that metalinguistic abilities precede 
literacy skills, which means that it would be virtually impossible to foresee an adequate literacy performance without previously developing learners' metalinguistic abilities. In the same line of research, Ehri (1978) states that whilst it might be enough to have implicit knowledge of a language in order to communicate orally, it is crucial to gain metalinguistic awareness to develop proper written communication. This type of awareness will influence different areas of language: phonological, semantic and syntactic awareness. As the result of some research carried out by Ehri (1984), this author claims that infants who are not yet familiar with reading but obtain good scores in metalinguistic tests, reach high levels of success and good results when starting their literacy training.

On the other hand, Olson (1995) describes writing as a metalinguistic activity in itself. This is so because oral metalanguage is imperative to become aware of and refer to written language, and because writing involves distinctions between sounds, letters, words, spaces, and the relations between them. Therefore, one can assert that writing develops certain areas of metalinguistic awareness, such as phonologic, semantic and syntactic levels.

As a consequence of all of the above, we can see how important it is for teachers to understand their pupils' metalinguistic awareness, as well as the tasks that develop such aspect. Phonologic awareness, for instance, is chiefly developed between the ages of 3 and 8. In addition, this kind of awareness will have to be developed through oral games (tongue twisters, songs, riddles, word sequences, etc.), and by means of comparing the sound of words and the individual sounds within words. This is how Berko Gleason and Bernstein Ratner (2010) believe it should be done. They confirm that numerous researches have concluded that children's ability to read and write is closely related to their phonologic awareness. It is also claimed that the greatest development of phonological awareness is reached as a result of teaching reading. This is due to the emphasis on the correspondence between sounds and symbols, which eases literacy acquisition.

On the whole, we can draw the conclusion that it is crucial to pay attention to metacognition and metalinguistic awareness during the different stages of literacy acquisition. In order to do so, it is important to bear in mind the results of studies carried out by Korkman and Peltomaa (1993) and Etchepareborda (2002), which emphasise the importance of developing learners' metacognitive, linguistic and metalinguistic awareness, especially when they show literacy difficulties. This will no doubt ease and ensure a better learning process. 


\section{Proposal: set of activities for educational intervention}

It is in this section that an intervention programme is devised and presented, taking into account the concepts and measures explained in previous sections, as well as the report of the pupil which was previously described. Therefore, a series of activities are proposed which will aid in planning a session or a succession of them. Bearing in mind that the child's mother tongue is Spanish, all of the activities and texts proposed are in Spanish.

Based on the knowledge of the teacher, the family's contributions and results of the psycho-pedagogical report, it has been decided to concentrate the efforts on catering for the pupils' literacy deficiencies, and on working towards an improvement of the learning processes involved in literacy acquisition. As a result, the activities contained in this proposal deal both with reading processes (perceptive, lexical, syntactic, semantic) and writing processes (basic, complex, motor):

\section{A) ACTIVITIES TO IMPROVE THE DEVELOPMENT OF READING PROCESSES}

\section{1.- Activities to improve perceptive processes}

1.1.- We will focus on the following groups of words, and will say the elements that change and do not change when read or written. For example, if we focus on the set of words Gata, Masa, Pasa, Rasa, we can tell that the only difference is the initial sound (oral) or the initial letter (written). The rest does not change (-asa). However, with the change of the first sound or letter, the meaning changes.

This happens with the following sets of words:

1) Gasa - Masa - Pasa - Rasa

2) Bata - Gata - Lata - Nata - Pata - Rata

3) Cala - Gala - Mala - Pala - Sala

4) Lisa - Misa - Pisa - Risa

1.2.- Now, we can divide those words into syllables. This would make us realise that they all have two syllables: Ga-sa; Ma-sa; Pa-sa, and Ra-sa.

You can do the same with the following words: lisa, misa, pisa, risa, camisa, iglesia; mármol; pelotazo; guerra; cuento; quesito; yo; camarero.

1.3.- As we see, words are made up of sound units (phonemes) that form larger units (syllables), and neither the sound units nor the syllables mean anything in

isolation. Knowing this, we are now going to identify the similarities and differences of the following groups of words, which are both similar and different:

1) Boca / foca

What is similar?

What is different?

What is the meaning of each word? 
Do the same with the following words (What is similar? What is different? What is the meaning of each word?):

1) Costura / postura

2) Loca / poca

3) Pintura / cintura

4) Balsa / salsa

5) Curiosa /furiosa

6) Cadera / codera

7) Madera / ladera

8) Lechera / pechera

9) Ranura / llanura.

1.4.- With the aim of using language playfully and develop our ability to utter sounds clearly and read texts accurately, we are going to focus on the following popular tongue twister:

Dondín no tiene don. ¿qué hace Dondín sin don?

Due to its simplicity, we are going to memorise it and recite it. First, we will do so very slowly; then, whispering, and finally, with a regular volume and adequate tone.

We can also work on this very same sound (/d/) with Rafael Alberti's following poem:

\section{DON DIEGO}

Don dondiego no tiene don, don.

Don dondiego de nieve y de fuego; don, din, don, que no tenéis don.

Ábrete de noche, ciérrate de día, cuida no te corte la tía María.

Don dondiego, que al sol estáis ciego; don, din, don, que no tenéis don.

1.5.- With the following poem, by Carlos Murciano, we can work on the sound /p/. The teacher should read it first so as to structure it rhythmically, and then the student, who should end up reading it speedily and accurately. 


\section{PATRICIA CON P}

Patricia pinta un palomo pillo, panzudo y pequeño: le pone púrpura el pico, le pone de plata el pecho.

El palomo de Patricia se ha posado en el perchero y ella le peina las plumas con la punta del pañuelo.

Pronto el palomo pasea,
presumido y postinero,
mientras Patricia se prende
una petunia en el pelo.

1.6.- In the same way we have enjoyed these poems, we are going to read, memorise and recite simple traditional tongue twisters, which play with a variety of phonemes or phonemic groups:

Canta el cuco: cuqui-cuco.

Canta el cuco: cuqui-cuca.

Canta el cuco. cuqui-cuco, cuqui-cuco-cuquicá.

Mi primo propuso

que probáramos aquel pastel.

Él lo probó primero

y yo lo probé después.

1.7.- In the same way, in order to read correctly, we ought to perceive sounds correctly and know how to distinguish them within words. We also have to become aware of the punctuation in any given text. We will improve our interpretation of punctuation and our reading skills by means of the following texts:

The first one was written by Rabindranath Tagore, and it goes as follows:

Oye, madre, las flores tendrán su casa en el cielo con las estrellas, ¿verdad? ¡Mira tú, si no, qué ganas tienen de subir! ¿Y a que no sabes tú por qué corren tanto? ¡Yo sí lo sé! Y sé también a quién echan sus brazos. Las flores tienen su madre como yo te tengo a ti.

The second one belongs to Juan Ramón Jiménez, and it goes as follows:

No sé si tú, Platero, sabrás ver una fotografía. Yo se las he enseñado a algunos hombres del campo y no veían nada en ellas. Pues éste es Lord, Platero, el perrillo Foxterrier de que a veces te he hablado. Míralo. Está, ¿lo ves?, en un cojín del patio de mármol, tomando, entre las macetas de geranios, el sol del invierno. 


\section{2.- Activities to improve lexical processes}

2.1.- Read the following words and make a list with the ones you consider easy to read and the ones you think are difficult: casa, mesa, guerra, luna, ciego, guerrera, quesería, merienda, abuelo, degüello, kilogramo, cuadrilátero, superprotección, merienda, desparpajo, paupérrimo, descuajaringado.

- Now we will divide the easy ones into its different syllables.

2.2.- Now we will do the same with the words we thought were difficult. Later we shall clarify the meaning of each word, and we will try reading them at an appropriate speed.

2.3.- In the following poem by Germán Berdiales, there is a playful use of the sounds /t/ and /p/. Firstly, read it in silence. Then try to identify which words have meaning and which do not. Underline the ones with meaning.

$$
\begin{aligned}
& \text { RONDA DEL ZAPATERO } \\
& \text { Tipi-tape, tipi-tape, } \\
& \text { tipi-tape, tipitón, } \\
& \text { tipi-tape, zape-zape } \\
& \text { Zapatero remendón. } \\
& \text { Tipi-tape todo el día, } \\
& \text { todo el año tipitón, } \\
& \text { tipi-tape, macha-macha } \\
& \text { machacando en tu rincón. } \\
& \\
& \text { Tipi-tape en tu banqueta, } \\
& \text { tipi-tape, tipitón, } \\
& \text { tipitón con tu martillo } \\
& \text { macha-macha, machacón. } \\
& \text { iAy, tus suelas, zapa-zapa } \\
& \text { zapatero remendón; } \\
& \text { ay tus suelas, tipi-tape, } \\
& \text { duran menos que el cartón! }
\end{aligned}
$$

Now we have to read the poem emphasising the sounds in each word. This should be done with a steady rhythm and good pronunciation, enjoying it as much as possible.

2.4.- Finally, we can do the same with other simple poems, such as the one by Antonio A. Gómez Yebra, who also plays with the sounds /b/ and /p/, which are easily confused both between them and with others that are written in a similar way $(/ \mathrm{d} /$ or $/ \mathrm{q} /)$. 


\author{
MI PELOTA \\ Esta pelota mía \\ bota, bota y bota. \\ Yo la tiro contra el suelo \\ y ella se eleva hacia el cielo \\ porque rebota. \\ Esta pelota mía \\ bota, bota y bota. \\ La arrojo hacia la pared \\ y ella regresa otra vez \\ porque rebota. \\ Esta pelota mía \\ bota, bota y bota. \\ Yo siempre seré su amigo \\ pues ella juega conmigo \\ mientras rebota.
}

\title{
3.- Activities to improve syntactic processes
}

3.1.- Focus on the importance of associating words in a sentence so as to read and understand a text correctly. To do so, we will see if in the following sentences the words are properly associated, or if they are not. If the latter is true, the sentences will not be understood properly:

La ardilla comían nueces.

Is it correct or incorrect?

If you think it is incorrect, how should we change it?

Why do we have to change it that way?

Do the same with the following sentences:

Este arroz con leche está muy mala.

La perrita no queja de su herida.

Mis amigos celebraron su cumpleaños en el cole.

El abono y el agua son buenas para las plantas.

3.2.- In order to know how words relate to each other in a sentence, we can practise with some strategies such as:

1) Putting sentences into the correct order. For example, we can do so with the following sentence: de matemáticas / cuando / yo / la gripe / el maestro / explicó / el tema / tenía. The result will be: El maestro explicó el tema de matemáticas cuando yo tenía la gripe. 
Taking the previous example, we can do the same with the following sentences whose elements are in the wrong order:

- vienen / en / Navidades / a / mis / del pueblo / casa / abuelitos / mi. - cuando / todas / los deberes / un rato / termino / las tardes / leo.

- jugar / García Lorca / mucho /en / el parque / al balón / gusta / me. - los sábados / mi / las macetas / todos / de / riego /mamá.

2) Expanding sentences. From a sentence with two elements (subject and predicate), we can continuously add information to make it more complete. For example:

-El niño come.

-El niño bueno come.

-El niño bueno come pan.

-El niño rubio come pan casero.

-El niño rubio come pan casero con chocolate.

-El niño rubio come pan casero con chocolate mientras está sentado.

-El niño rubio come pan casero con chocolate mientras está sentado en un banco.

-El niño rubio come pan casero con chocolate mientras está sentado en un banco de la plaza.

-El niño rubio come pan casero con chocolate mientras está sentado en un banco de la plaza de su barrio.

Do the same with the following sentence: La niña bebe.

3) Reducing sentences. Now we shall do exactly the opposite to what we have done in 2). We start with a paragraph or a sentence more or less complex, and we end up with its essential elements (subject and predicate). For example:

- El niño rubio, que viene todos los días al colegio, come pan casero con chocolate muy rico en la hermosa plaza de su pueblo.

- El niño rubio come pan casero con chocolate muy rico en la hermosa plaza de su pueblo.

- El niño come pan con chocolate en la hermosa plaza de su pueblo.

- El niño come pan con chocolate en la plaza de su pueblo.

- El niño come pan con chocolate en la plaza.

- El niño come pan con chocolate.

- El niño come pan.

- El niño come.

Now do the same with this text: La niña morena que va todas las semanas a la peluquería come ricos helados de vainilla en la heladería de su primo Andrés.

3.3.- We are now going to work with the rest of the classmates. We are going to ask questions about some sentences in order to understand better and think about the relation between the construction of sentences and their meanings.

1A) Después de acabar de merendar, Luis se puso a ver la televisión. What did Luis do first?

How do you know?

1B) Luis se puso a ver la televisión después de terminar de merendar. 


\section{What did Luis do after? \\ How do you know?}

1C) Now we look at both sentences together:

- Después de acabar de merendar, Luis se puso a ver la televisión.

- Luis se puso a ver la televisión después de terminar de merendar.

Do these to sentences mean the same?

How do you know?

2A) El perro arremetió contra el gato.

What did the dog charge at?

How do you know?

2B) El gato arremetió contra el perro.

What did the cat charge at?

What did you look at to come up with your answer?

2C) We repeat the two previous sentences:

El perro arremetió contra el gato.

El gato arremetió contra el perro.

Do they mean the same?

How do you know?

\section{4.- Activities to improve semantic processes}

4.1.- To understand the meaning of any text we read, we have to pay attention to the way things are expressed. For this reason, let's focus on the following sentences and answer the questions:

1A) La niña tomó el bocadillo antes de leer el cómic.

1B) La niña, después de tomar el bocadillo, se puso a leer el cómic.

Do they mean the same?

How do you know?

2A) La mamá está ante su hija.

2B) La hija está detrás de su mamá.

Do they mean the same?

How do you know?

3A) En este cesto hay más manzanas que peras.

3B) En este cesto hay menos peras que manzanas.

Do they mean the same?

How do you know?

4.2.- Now notice that some of the words in the following sentences have more than one possible meaning. In order to know the meaning of the sentence, we should know all the different meanings of those words. For example, if we say: 
What is the meaning of "Tenía un gato en mi casa”? Did I have that pet we all know about which hunts mice? That may be true, but I could also be referring to the tool we use to lift cars when changing a wheel. In that case, the meaning of the sentence is totally different.

Now let's find out what the meanings of the words are in these sentences:

\section{Esta sierra es muy peligrosa}

What are the meanings of the word sierra?

With the first meaning of sierra, what is the meaning of the sentence Esta sierra es muy peligrosa?

Did you find another meaning? What other meaning could the same sentence have?

\section{La pluma era marrón}

What are the meanings of the word pluma?

With the first meaning of pluma, what is the meaning of the sentence $L a$ pluma era marrón?

Did you find another meaning? What other meaning could the same sentence have?

\section{La lechera se cayó al suelo}

What are the meanings of the word lechera?

With the first meaning of lechera, what is the meaning of the sentence $L a$ lechera se cayó al suelo?

Did you find another meaning? What other meaning could the same sentence have?

\section{Tenía la muñeca rota}

What are the meanings of the word muñeca?

With the first meaning of muñeca, what is the meaning of the sentence Tenía la muñeca rota?

Did you find another meaning? What other meaning could the same sentence have?

\section{Este cabo es muy pequeño}

What are the meanings of the word cabo?

With the first meaning of cabo, what is the meaning of the sentence Este cabo es muy pequeño?

Did you find another meaning? What other meaning could the same sentence have? 


\section{B) ACTIVITIES TO IMPROVE THE DEVELOPMENT OF WRITING PROCESSES \\ 1.- Activities to improve basic processes
1.1.- When writing, we must make sure that we separate the individual words
correctly. To practise, separate this famous paragraph by Azorín: \\ Estehombreviveenelcamposucasaestálejosdelaciudadsucasaespequeñísima. \\ Once you have separated the words, copy the paragraph properly. \\ 1.2.- The following text belongs to a children's short traditional story. Separate them and write the story correctly. \\ Esteeselcuentodelgallopeladoquedelargoqueerayasehaacabado.}

1.3.- We are now going to learn to write by following the text below by M. Artigos. We should notice the perfect use of the full stop, and the use of capital letters after it. Besides, the spelling of some words is difficult, especially with the use of "s" or "c". Firstly, read it in silence. Then, read it aloud, making sure you make all the pauses. Finally, copy it trying to avoid spelling mistakes.

TEXT:

El año tiene cuatro estaciones y doce meses.

Las estaciones se llaman primavera, verano, otoño e invierno.

La primavera es la estación más bonita y más alegre de todas.

No hace frío ni calor.

El clima es bueno.

Los animales están alegres y el campo se llena de flores.

Por eso la primavera nos gusta a todos.

Read the following text extracted from El Principito (first in silence and then aloud). Once you have understood the meaning of all the words, underline all the words that have "r" or "rr". We are going to learn why we write "r" or "rr".

\section{TEXT:}

Todos los días, cuando uno termina su baño matinal, hay que ocuparse de limpiar cuidadosamente la casa y la tierra que la rodea, arrancando las pequeñas plantas malas, las cuales hay que saber distinguir de las de los rosales, ya que se parecen mucho cuando son pequeñas.

Now we can write sentences with the words we have underlined, paying special attention to "r" and "rr".

1.4.- We shall now carry out copying and dictation exercises in order to remedy spelling deficiencies. We will start with simple texts, reading in silence; then, aloud; we will learn the meaning of any unknown words; we will underline and 
copy the words with difficult spelling; we will copy the text and, finally, we will carry out some dictations.

\section{2.- Activities to improve motor processes}

2.1.- Carrying out very short dictations (previously separated) and calligraphic copying exercises at word and sentence level, trying to join letters and separate words appropriately. It is also important to maintain the size of writing throughout.

2.2.- Writing compositions in a clear handwriting and with a neat layout, including an appropriate use of different colours, margins, spacings, etc.

2.3.- Creating murals with newspapers and magazines cut-outs, focusing on a good presentation and layout, and on the legibility of the texts (spacing, margins, etc.).

\section{3.- Activities to improve complex processes}

3.1.- We improve our written compositions trying not to do it by improvising, but by knowing what we have to write, to whom, what to say, how to organise our message, and how to express it clearly. To do so, we will practise our writing with the free text, writing about what one wishes and when one wishes to. But before writing, one should decide who we are writing to, what for, what we want to convey, how, etc. Then we will draft the first version.

3.2.- With a text that we have previously written, we should learn to proofread, revise and correct it. This should be done through reading carefully what we previously wrote and giving it to other to read (peers, teachers), and then correcting the mistakes we have found.

3.3. We must learn to write texts in a coherent and appropriate way, editing our drafts and making sure that the layout is suitable (no smudges, no cross-outs, neat handwriting...)

3.4.- Spotting incoherences. Many times some texts cannot be understood because there is no coherence. In order to make sure that our text makes sense, it has to be coherent. Now identify the incoherences in the following sentences and explain why they are incoherent. Then, express them in a coherent way.

- Luis tiene veinte años y su abuelo, quince.

- Los doce meses del año son seis: enero, febrero, junio y diciembre.

- Mi prima y su amiga van a la guardería de mi barrio, que su madre es amiga de la maestra, que es mayor.

- Esta mesa rectangular es redonda.

- He pintado de distintos colores cada uno de los cuatro ángulos del triángulo

- Los Reyes Magos son tres: Melchor y Gaspar y otros dos de los que no me acuerdo.

- Mi amiga vive en una casa muy bonita y la fiesta se celebró hace dos semanas.

3.5.- Compose a topic. Write about a topic which is known to you because you learnt about it in class. For example: Los animales domésticos.

Before improvising on paper, try to follow these steps:

- Think about who will read it. 
- Look for ideas and information about what you want to write (in your book, on the Internet, asking your parents, asking your teacher, etc.). Never start to write without having a clear idea of what you want to say.

- Put your ideas into sentences that summarise what you want to say.

- Give these sentences an order and write them in a logical order.

- Write your first draft.

- Read your draft and change what you think can be improved. Hand this draft to your classmates or to the teacher. They will provide you with useful opinions and corrections.

- Make any other pertinent changes and corrections, and when you think that your text is coherent and correct, write the final text.

Finally, taking into account the learning style of this child and his low achievement in relation to what is stated by the Register of Curricular Competence Level, it must be stated that the family, the teacher and the pedagogic therapist must work in conjunction so as to enable this child to reach a greater level of maturity as well as greater learning autonomy. Likewise, it is advisable to work with short and motivating activities that will succeed both academically and at a personal level, fostering selfconfidence and self-esteem.

\section{References:}

Berko Gleason, J. and Bernstein Ratner, N. (2010). Desarrollo del lenguaje. Madrid: Pearson.

Cuetos Vega, F. (1990). Psicología de la Lectura. Diagnóstico y tratamiento de los trastornos de lectura. Madrid: Escuela Española.

Cuetos Vega, F. (1991). Psicología de la Escritura. Diagnóstico y tratamiento de los trastornos de escritura. Madrid: Escuela Española.

Ehri, L.C. (1978). Beginning reading from a psycholinguistic perspective: Amalgamation of word identities. In F. B. Murray (Ed.). The Development of the Reading Process, International Reading Association Monograph (No. 3) (pp 1-33). Newark (Del): International Reading Association. Ehri, L.C. (1984). How orthography alters spoken language competencies in children learning to read and spell. In J. Downing \& R. Valtin (Eds.). Language Awareness and Learning to read (pp. 119-147). New York: Springer-Verlag.

Etchepareborda, M.C. (2002). Detección precoz de dislexia y enfoque terapéutico. Revista de neurología, 32, 13-23.

Etchepareborda M.C. and Habib M. (2001). Bases neurobiológicas de la conciencia fonológica: su compromiso en la dislexia. Revista de 
Neurología Clínica, 2, 5-23.

Flower, L. and Hayes, J.R. (1981). A cognitive Process. Theory of Writing. In College Composition and Communication, 32. Illinois.

Galve Manzano, J.L. (2007). Evaluación e intervención en los procesos de la lectura y la escritura. Madrid: EOS.

González Rus, G. and Ramos Chofle, J. (2012). La Dislexia. Concepto, Diagnóstico e Intervención. Unidad 2: La lectura y la escritura desde un enfoque cognitivo. [DOC] Online course through CEP Granada, FebruaryJune, 2012.

Korkman, M. and Peltomaa, K. (1993). Preventive treatment of dyslexia by a preschool training program for children with language impairments. Journal of Clinical Child Psychology, 22, 277-287.

Núñez M. ${ }^{a}$ P. (2011). Didáctica de las habilidades lingüísticas en la educación inicial. Madrid: ITEM multimedia. ISBN: 978-84-96677-29-6.

Olson, D. R. (1995). La cultura escrita como actividad metalingüística. In D. Olson and N. Torrance (Eds.): Cultura crítica y oralidad (pp. 333-357). Barcelona: Gedisa.

Pinto, M. ${ }^{a}$ A., Titone, R. and González Gil, M. ${ }^{a}$ D. (2000). La consciencia metalingüística. Teoría, desarrollo e instrumentos de medición. Pisa-Roma: Istituti Editoriali Poligrafici Internazionali.

Sánchez Merchán, L. M. and Coveñas Rodríguez, L. (2011). Dislexia: un enfoque multidisciplinar. Alicante: Club Universitario.

Santa Olalla, G. and Bilbao León, M.C. (2002). Evaluación e Intervención en las Dificultades de Aprendizaje de la Expresión Escrita. In E. Del Campo Adrián, Dificultades de Aprendizaje e Intervención Psicopedagógica. Volumen II. Madrid: Sanz y Torres.

Tunmer, W.E., Pratt, C. \& Herriman, M.L. (1984) (Eds.). Metalinguistic Awareness in Children. Theory, Research and Implications. Berlin: Springer-Verlag. 